DOI 10.31558/2519-2949.2019.2.4

УДК 340.116:316

ORCID ID: https://orcid.org/0000-0003-3922-7619

Чальцева О. М., Донецький національний університет імені Василя Стуса

\title{
МОЖЛИВОСТІ І ПРОБЛЕМИ ОТРИМАННЯ ВИЩОЇ ОСВІТИ ДІТЬМИ З ОКУПОВАНИХ ТЕРИТОРІЙ
}

У 2014 р. з початком російської агресії, перед українською держсавою гостро постали питання щодо прав дітей з окупованих територій. Одним з таких питань було надання можливостей в отримані вищої освіти для молоді, яка має бажання навчатись в Україні.

В науковій літературі дана проблема ще не достатньо досліджена. Аналізом питань, які стосуються внутрішньо переміщених осіб, займалися зарубіжні та вітчизняні дослідники через призму соціальних, міграційних, політико-правових, психологічних аспектів.

В статті проаналізовані правові можливості та проблеми їх реалізаиї̈, щодо отримання вищої освіти дітьми з окупованих територій.

Прийняті закони про забезпечення прав і свобод громадян та правовий режим на тимчасово окупованій території України встановлювали, щсо громадяни України, які прожсивають на тимчасово окупованих територіях і особи, які були з неї переміщені мають право на продовження свого навчання на іншій території України за рахунок коштів державного бюджету. Проте, на даний момент прочедура досі до кіния так і не затверджена і потребує свого законодавчого уточнення та вироблення більш чітких $і$ зрозумілих механізмів вирішення.

За допомогою освітніх иеетрів «Донбас - Україна» $i$ «Крим - Україна», на основі запропонованого порядку, дітям з територій проведення операції об'єднаних сил відкрився новий шлях для отримання атестатів і вступу до вищих навчальних закладів на території України. Основне завдання освітніх иентрів - це супровід і допомога абітурієнтам, які прожсивють на території, непідконтрольній Україні, в отриманні атестата про повну загальну середню освіту та вступі до украӥнських вишів.

Проблеми реалізачї права на вищу освіту ВПО включають в себе: фінансові, психологічні, сочіальні та ін. проблеми.

Ключові слова: внутрішньо переміщені особи, заклади вищої освіти, вища освіта, окуповані території, права дітей, адаптачія.

3 початком окупації Криму і частини Донбасу Російською Федерацією в 2014 р., перед українською державою гостро постали питання щодо прав дітей з окупованих територій. Одним 3 таких питань було надання можливостей в отримані вищої освіти для молоді, яка має бажання навчатись в Україні. 3 цією проблемою український політикум зіткнувся вперше у своїй історії, i тому вирішення її є складним і суперечливим процесом, як у стратегічному, так і в тактичному сенсі.

В науковій літературі дана проблема ще не достатньо досліджена. Аналізом питань, які стосуються внутрішньо переміщених осіб, займалися зарубіжні та вітчизняні дослідники через призму соціальних, міграційних, політико-правових, психологічних аспектів: Г. Гудвін-Гілл, Л. Холборн, Т. Хаммар, С. Комаров, В. Потапова, Т. Юдіна, А. Ястребова, О. Бандурка, С. Бритченко, О. Гончаренко, Н. Грабар, І. Ковалишин, Л. Шамільова, А. Амоша, В. Антонюк, Н. Бортник, І. Хомишин та ін. Проте, по причині невирішеності проблеми та постійних змін і оновлень, щодо внутрішньо переміщених осіб в політико-правовому полі, тема ще знаходиться у стані розробки та осмислення.

В статті проаналізовані правові можливості та проблеми їх реалізації, щодо отримання вищої освіти дітьми з окупованих територій.

Перші політико-правові рішення, щодо подолання освітніх проблем на окупованих територіях носять переважно загальний, ситуативний характер і мають багато недоліків. Так, з початком окупації в 2014 р. Криму, а потім частини Донбасу для України, в першу чергу, необхідно було виробити правовий алгоритм, за яким би діти з неконтрольованих територій могли б без перешкод поступати до закладів вищої освіти (далі 3ВО) в Україні. Так, першим документом, який регулював 
загальні питання внутрішньо переміщених осіб (далі ВПО) був Закон «Про забезпечення прав і свобод громадян та правовий режим на тимчасово окупованій території України» (2014p.) [1], прийнятий на підставі міжнародного законодавства "Керівних принципах з питань про переміщених осіб всередині країни" УВКБ ООН [2]. Документ декларував право на продовження здобуття певного освітнього рівня на території інших регіонів України за рахунок коштів державного бюджету або інших джерел фінансування. Стаття 11 цього ж закону встановлювала, що Міністерство освіти і науки України повинно створити умови для здобуття освіти громадянами.

В цьому ж Законі були прописані можливості для дітей, які були зареєстровані, як ВПО отримати освіту, в тому числі і вищу. Так, наприклад, держава мала забезпечувати дітям, у тому числі дітям, які навчаються за денною формою навчання у закладах вищої освіти, державну цільову підтримку для здобуття вищої освіти у державних та комунальних навчальних закладах до їх закінчення.

Незважаючи на те, що «окупації» Криму і частини Донбасу носили різний характер (Крим без воєнного вторгнення і включенням до складу Російської Федерації, Донбас через бойові дії і створення невизнаних республік), держава мала вирішити наступні питання щодо отримання вищої освіти дітьми з окупованих територій. По-перше, необхідно було розробити механізм і правила переводу студентів, які вже навчались в ЗВО в Донецькій і Луганській області та Криму на момент окупації. По-друге, виробити умови вступу до ЗВО вступникам у 2014 р. Перше питання вирішували наступним чином, студентам було запропоновано обрати ЗВО в Україні і перевестись зі своїм бюджетним місцем. Студенти контрактники переводились без перешкод в будь який ЗВО. Складніше було студентам з Донбасу, тому що бойові дії, які були в активній фазі в цей час демонстрували можливість витиснення ворога з окупованих територій. Тому частина студентів не робили кроків відносно переводу в інші ЗВО. По-третє, забезпечення умов адаптування дітей з окупованих територій в українських ЗВО.

Для вступників-випускників 2014 року, які переселилися з тимчасово окупованої території України та за результатами конкурсного відбору у державні та комунальні навчальні заклади не потрапили на місця державного замовлення, був розроблений $\mathrm{i}$ досі $\epsilon$ чинним механізм, затверджений постановою Кабінету Міністрів України від 17 вересня 2014року № 450 [3]. Відповідно до нього, керівники ЗВО, в разі наявності таких вступників, мають можливість звернутись з пропозицією щодо внесення змін до обсягу державного замовлення до центрального органу виконавчої влади (Міністерства освіти і науки України), уповноваженого надати (розмістити) додаткові місця державного замовлення з урахуванням напряму підготовки (спеціальності), обраного вступником(ами) (пункти 1, 3-6 Порядку) [4].

23 листопада 2016 р. Кабінет Міністрів України із запізненням на рік, затвердив Порядок та умови надання державної цільової підтримки деяким категоріям громадян для здобуття професійнотехнічної та вищої освіти [5]. Порядок прийнято на виконання Закону України “Про внесення змін до деяких законів України щодо державної підтримки учасників бойових дій та їхніх дітей, дітей, один із батьків яких загинув у районі проведення антитерористичних операцій, бойових дій чи збройних конфліктів або під час масових акцій громадянського протесту, дітей, зареєстрованих як внутрішньо переміщені особи, для здобуття професійно-технічної та вищої освіти" від 14 травня 2015 року № 425-VIII. Відповідно до вказаного Закону Порядок мав бути прийнятим в термін до 5 липня 2015 року, однак в цього не відбулося [6].

Протягом 2017-19 рр. були прийняті нові правові документи уточнюючого характеру щодо статусу ВПО та їх прав в різних сферах життях. Серед таких документів можна назвати, Розпорядження Кабінету Міністрів України від 15.11.2017 р. №909-р «Про схвалення Стратегії інтеграції внутрішньо переміщених осіб та впровадження довгострокових рішень щодо внутрішнього переміщення на період до 2020 року» [7], та від 11.01.2017 p. №8-p «Про затвердження плану заходів, спрямованих на реалізацію деяких засад державної внутрішньої політики щодо окремих районів Донецької та Луганської областей, де органи державної влади тимчасово не здійснюють свої повноваження» [8].

Таким чином, прийняті закони про забезпечення прав і свобод громадян та правовий режим на тимчасово окупованій території України встановлювали, що громадяни України, які проживають на тимчасово окупованих територіях і особи, які були з неї переміщені мають право на продовження свого навчання на іншій території України за рахунок коштів державного бюджету. Проте, на даний момент процедура досі до кінця так і не затверджена і потребує свого законодавчого уточнення та вироблення більш чітких і зрозумілих механізмів вирішення. 
Ще одна проблема, яка стоїть перед українськими законотворцями - це можливість отримання освіти молоддю в тих ЗВО, які вимушено переїхали на неокуповану Україну та тих, які знаходяться в неокупованій частині Донецької і Луганської областей. Починаючи з вересня ЗВО, які попали в зону окупації були вимушені приймати рішення, щодо продовження своєї діяльності на території України. Серед таких 3ВО Донецької (10) та Луганської (7) областей слід назвати: Донецький національний університет імені Василя Стуса (Вінниця), Донецький національний технічний університет (Покровськ), Донецький державний університет управління (Маріуполь), Луганський національний університет імені Тараса Шевченка (Старобільськ), Східноукраїнський національний університет імені Володимира Даля (Сєвєродонецьк) та ін. 3 Криму був переміщений один ЗВО - це Таврійський національний університет імені Володимира Івановича Вернадського (Київ)[10]. Та частина студентів, які наважились переїхати зі своїми вишами в інші міста України, були найбільш вразливою категорією переміщених осіб, які і в індивідуальному порядку мали невизначений статус, i їx ЗВО також були в стані екстремального поновлення навчального процесу без необхідних матеріальних умов.

Відповідно до Наказів МОН України № 105 від 30.01.2017 року № 697 від 21.06.2017, № 238 від 07.03.2018 розроблено «Порядок прийому для здобуття вищої та професійно-технічної освіти осіб, місцем проживання яких є територія проведення операції об'єднаних сил (на період іiі проведення) [11]. Відповідно до цього Наказу були створені освітні центри «Донбас- Україна» і «Крим - Україна». На основі запропонованого порядку, дітям 3 територій проведення операції об'єднаних сил відкрився новий, значно простіший шлях для отримання атестатів і вступу до вищих навчальних закладів на території України. Основне завдання освітніх центрів - це супровід $\mathrm{i}$ допомога абітурієнтам, які проживають на території, непідконтрольній Україні, в отриманні атестата про повну загальну середню освіту та вступі до українських вишів.

Спрощена система вступу без необхідності складати ЗНО діятиме до тих вишів, на базі яких працюватимуть освітні центри. МОН України з цією метою затвердила Перелік вищих навчальних закладів, що розташовані на території Луганської та Донецької областей, де здійснюють свої повноваження обласні військово-цивільні адміністрації (24), та перелік вищих навчальних закладів, які було евакуйовано з території проведення антитерористичної операції (на період іï проведення) (17), на базі яких створено освітні центри «ДОНБАС-УКРАЇНА». Діяльність освітніх центрів дійсно $є$ позитивним кроком влади до отримання дітьми з окупованих територій вищої освіти [12].

Проте, необхідно зазначити, що існує багато проблем щодо отримання освіти ВПО, які необхідно вирішувати. Так, проблеми реалізації права на вищу освіту ВПО, виокремила в своїх роботах I. Хомишина. Вона звертає увагу, що серед найбільш поширених що стосуються навчального процесу можемо виділити такі:- необхідність ліквідації академічної різниці, яка в окремих випадках становила велику кількість навчальних дисциплін; перезарахування раніше складених предметів. У зв'язку із відсутністю завірених копій залікових книжок, оригіналів особових справ тощо, вищі навчальні заклади часто відмовляють студентам у перезарахуванні раніше складених предметів, що спричинює збільшення академічної заборгованості; неможливість отримання оригіналів документів із попереднього місця навчання. Також студенти-переселенці гостро відчувають таку соціально-економічну проблему, як відсутність достатньої кількості місць у студентських гуртожитках [13].

Наступна проблема - це безоплатне проживання в гуртожитках. Нажаль, незважаючи на наявність відповідного положення у Законі України “Про вищу освіту" проживання в гуртожитках ВПО, які навчаються у вишах не є безоплатним. Для ВПО передбачена лише пільгова оплата за проживання у гуртожитку і тільки за умови, якщо така ВПО не отримує щомісячну адресну допомогу.

Не менш суттєвою $є$ також матеріальна проблема - це отримання щомісячної допомоги. Згідно 3 чинним законодавством не отримують щомісячну адресну допомогу тільки ВПО студенти, будьхто з членів сім'ї яких має у власності житлове приміщення, розташоване на території, підконтрольній Уряду України та будь-хто з членів сім'ї яких має на депозитному банківському рахунку кошти у сумі, що перевищує 10-кратний розмір прожиткового мінімуму, встановленого для працездатних осіб (станом на 4 січня це 16000 грн.) Це означає, що найбільш вразливі ВПО, які не мають власного житла та заощаджень, не отримають навіть пільг по оплаті, не кажучи вже про безоплатне проживання в гуртожитку.

Ще одна проблема - це оплата навчання за кошти державного та місцевого бюджетів. На відміну від гарантій Закону України “Про вищу освіту” щодо повної або часткової оплати навчання 
за кошти державного та місцевих бюджетів, Закон України не роз'яснює як це здійснюється. Наприклад, Державний бюджет України на 2017 рік не передбачав фінансування державної цільової підтримки. Отже, ВПО мають спеціальні права під час проходження конкурсу на вступ до вишу, проте це не надає їм гарантії наявності місць для навчання за кошти державного або місцевих бюджетів.

Соціальна та психологічна адаптація студентів з окупованих територій до навчання в Україні це наступна проблема, яку необхідно виокремити. На думку, Ю. Кращенко та Г. Сорокіної,чіткого державного механізму допомоги студентампереселенцям в адаптації до нового середовища на сьогодні немає. На підставі проведеного вищеозначеними вченими дослідження, можна побачити, що о 64 \% студентів мають труднощі у адаптації до нового навчального середовища Психологічні проблеми, пов'язані з руйнуванням колишнього звичного способу життя в рідному місті, раптовий розрив соціальних зв'язків зі своїми родичами, друзями, невизначеність свого майбутнього, занепокоєння за своїх родичів, які залишилися, пригнічують студентів з родин внутрішньо переміщених осіб, однаковою мірою (23-25 \% опитаних) як проблеми матеріального характеру (проживання, харчування, витрати на навчання і т.ін.) [14].

Особливе місце проблема адаптації посідає у студентів-переселенців, які є найбільш вразливою соціальною групою в контексті міграційних процесів. За вірним зауваження В.Г. Дуб, студентипереселенці - це особлива вікова і соціальна категорія населення, що характеризується цілим спектром специфічних проблем. Зміна соціального статусу і оточення, входження в нове соціокультурне та освітнє середовище, особиста і матеріальна невлаштованість, підвищена порівняно з іншими віковими категоріями осіб значимість та потреба тісних емоційних контактів 3 одночасним страхом відчуження, криза ідентичності- ось далеко не весь перелік цих проблем. Зміни зовнішнього середовища вимагають від людини тих чи інших форм реакцій, що залежно від характеру адаптації можуть бути більш чи менш адекватними[15].

Особливістю адаптації студентів-переселенців до нового університетського середовища $є$ те, що вона супроводжується цілою низкою важливих проблем з якими стикається студент: економічні, соціальні, побутові, організаційні, психологічні, а іноді мають місце й правові колізії.

Розглядаючи проблему адаптації студентів-переселенців до навчального закладу, можна виокремити дві основні групи труднощів, які негативно впливають на процес входження переселенців у студентську спільноту. До першої групи відносяться навчально-організаційні труднощі. Це ті проблеми, які виникають при організації навчально-виховного процесу у виші та організації життя студента поза межами університету. Сюди можемо віднести підтвердження свого статусу у зв'язку з втратою документів, велика академрізниця, яку необхідно перескласти, нове оточення, відсутність навичок самостійної роботи, незнання своїх прав, пропуски занять, надання переваги вирішенню побутових, матеріальних, соціальних, економічних проблем над навчанням, проблеми 3 поселенням в гуртожитки, нові навчальні дисципліни та способи їх викладання, відсутність матеріально-технічної бази й базових умов для навчання та життя, недостатню кількість викладачів, проблеми з гуртожитками, зі стипендіями і фінансуванням, проблему зарахування тимчасово переміщених осіб на вільні бюджетні місця, необхідність визначення та ліквідації академічної різниці, перезарахування раніше складених предметів, неможливість отримання оригіналів документів із попереднього місця навчання, новий маршрут до місця навчання [16].

До другої групи відносяться психологічні труднощі, які проявляються у підвищенні показника емоційного збудження, тривожності, нейротизму; зниженні комунікабельності, емоційної стійкості, самоконтролю, соціальної сміливості; появі почуття неповноцінності та ізольованості у стосунках із одногрупниками, викладачами, некомунікабельність, труднощі, пов'язані з мовними особливостями, а в поведінці в цілому спостерігається надмірна сором'язливість, закритість, прояв негативізму до «чужих»; зниженні успішності, відсутній мотивації до навчання, недостатній увазі й зосередженості на заняттях, труднощі у процесі сприйняття й осмислення студентами матеріалу, який вивчається; скаргах на погане самопочуття, сон; втраті інтересу до навчання, школи [17]. Внаслідок цих проявів розвиваються адаптаційний стрес, непродуктивні форми реагування, симптоми порушення поведінки, емоційні розлади різного ступеня.

Таким чином, права дітей з окупованих територій на вищу освіту в Україні вирішуються, але 3 різним успіхом. Безумовно, ми не можемо не побачити конкретні позитивні зрушення в питанні формування правової основи з цієї проблеми. Але механізмів реалізації , вже створених правових умов в сучасній політиці гальмується. 


\section{Бібліографічний список}

1. Закон України від 15.04.2014 p. №1207-VII «Про забезпечення прав і свобод громадян та правовий режим на тимчасово окупованій території України». Офіційний веб-портал Верховної Ради України. URL: http://zakon3.rada.gov.ua/laws/show/1207-18

2. Керівні принципи ООН з питань переміщених осіб в середині країни від 22.07.1998.

URL: http://www.un.org/ru/documents/decl_conv/conventions/internal_displacement_principles.shtml

3. Деякі питання надання (розміщення) додаткових місць державного замовлення на підготовку фахівців, наукових, науково-педагогічних кадрів для громадян України, які проживають на тимчасово окупованій території або переселилися з неї: постанова Кабінету Міністрів України від 17 вересня 2014року №450 URL: http://zakon0.rada.gov.ua/laws/show/450-2014-\%D0\%BF

4. Там само.

5. Постанова Кабінету Міністрів України від 23.11.2016 р. №975 «Про надання державної цільової підтримки деяким категоріям громадян для здобуття професійно-технічної та вищої освіти // Урядовий портал / URL: https://www.kmu.gov.ua/ua/npas/249614440

6. Закон України від 14.05.2015 p. №425-VIII «Про внесення змін до деяких законів України щодо державної підтримки учасників бойових дій та їхніх дітей, дітей, один із батьків яких загинув у районі проведення антитерористичних операцій, бойових дій чи збройних конфліктів або під час масових акцій громадянського протесту, дітей, зареєстрованих як внутрішньо переміщені особи, для здобуття професійно-технічної та вищої освіти». Офіційний веб-портал Верховної Ради України URL: http://zakon2.rada.gov.ua/laws/show/425-19

7. Розпорядження Кабінету Міністрів України від 15.11.2017 p. №909-р «Про схвалення Стратегії інтеграції внутрішньо переміщених осіб та впровадження довгострокових рішень щодо внутрішнього переміщення на період до 2020 року» // Міністерство з питань тимчасово окупованих територій та внутрішньо переміщених осіб України. URL: http://mtot.gov.ua/5891-2/

8. Розпорядження Кабінету Міністрів України від 11.01.2017 p. №8-р «Про затвердження плану заходів, спрямованих на реалізацію деяких засад державної внутрішньої політики щодо окремих районів Донецької та Луганської областей, де органи державної влади тимчасово не здійснюють свої повноваження» // Офіційний веб-портал Верховної Ради України URL: http://zakon3.rada.gov.ua/laws/show/8-2017-\%D1\%80

9. Закон України від 16.05.2017 р. №2026-VIII «Про внесення змін до Закону України «Про вищу освіту» щодо забезпечення права на здобуття вищої освіти осіб, місцем проживання яких є тимчасово окупована територія України» // Офіційний веб-портал Верховної Ради України. URL: http://zakon3.rada.gov.ua/laws/show/2026-19

10. Наказ МОН України № 50 від 26.01.2016 "Про утворення Ради ректорів вищих навчальних закладів, які тимчасово переміщені із зони проведення антитерористичної операції".

URL: http://zakon3.rada.gov.ua/laws/show/2026-19

11. Наказ МОН України «Про затвердження Порядку прийому для здобуття вищої та професійної (професійно-технічної) освіти осіб, місцем проживання яких $є$ тимчасово окуповані території у Донецькій та Луганській областях» URL: https://zakon2.rada.gov.ua/laws/show/z0907-16

12. https://mon.gov.ua/ua/zhitelyam-donbasu-ta-krimu/studentam/osvitni-centri/osvitni-centri-donbas-ukrayina

13. Хомишин І. Реалізація права на освіту внутрішньо переміщеними особами.

URL: http://science.lpnu.ua/sites/default/files/journal-paper/2018/jun/13343/30.pdf

14. Кращенко Ю., Сорокіна Г. Умови адаптації внутрішньопереміщених осіб до університетського середовища засобами студентського самоврядування. Витоки педагогічної майстерності. 2016. Випуск 17 URL: http://dspace.pnpu.edu.ua/bitstream/123456789/7591/1/Kraschenko.pdf

15. Дуб В.Г.Адаптація студентів-переселенців до вищого навчального закладу

URL:https://otherreferats.allbest.ru/sociology/00841607_0.html

16. http://vpl.com.ua/uk/news

17. Там само.

\section{References}

1.Zakon Ukrayiny` vid 15.04.2014 r. \#1207-VII «Pro zabezpechennya prav i svobod gromadyan ta pravovy“j rezhy'm na ty'mchasovo okupovanij tery`toriyi Ukrayiny'». Oficijny'j veb-portal Verxovnoyi Rady` Ukrayiny'. URL: http://zakon3.rada.gov.ua/laws/show/1207-18

2.Kerivni pry `ncy'py` OON z py'tan` peremishheny`x osib v seredy`ni krayiny` vid 22.07.1998. URL: http://www.un.org/ru/documents/decl_conv/conventions/internal_displacement_principles.shtml

3. Deyaki py tannya nadannya (rozmishhennya) dodatkovy'x miscz' derzhavnogo zamovlennya na pidgotovku faxivciv, naukovy'x, naukovo-pedagogichny'x kadriv dlya gromadyan Ukrayiny', yaki prozhy'vayut' na ty'mchasovo okupovanij tery 'toriyi abo peresely 'ly'sya z neyi: postanova Kabinetu Ministriv Ukrayiny` vid 17 veresnya 2014roku \#450 URL: http://zakon0.rada.gov.ua/laws/show/450-2014-\%D0\%BF

4.Postanova Kabinetu Ministriv Ukrayiny` vid 23.11.2016 r. \#975 «Pro nadannya derzhavnoyi cil’ovoyi pidtry`mky` deyaky`m kategoriyam gromadyan dlya zdobuttya profesijno-texnichnoyi ta vy`shhoyi osvity` // Uryadovy'j portal//URL: https://www.kmu.gov.ua/ua/npas/249614440

5.Zakon Ukrayiny` vid 14.05.2015 r. \#425-VIII «Pro vnesennya zmin do deyaky`x zakoniv Ukrayiny` shhodo derzhavnoyi pidtry 'mky` uchasny 'kiv bojovy`x dij ta yixnix ditej, ditej, ody`n iz bat'kiv yaky’x zagy`nuv u rajoni 
provedennya anty`terory`sty`chny`x operacij, bojovy`x dij chy`zbrojny`x konfliktiv abo pid chas masovy`x akcij gromadyans 'kogo protestu, ditej, zareyestrovany`x yak vnutrishn`o peremishheni osoby', dlya zdobuttya profesijnotexnichnoyi ta vy`shhoyi osvity`». Oficijny`j veb-portal Verxovnoyi Rady` Ukrayiny`.

URL: http://zakon2.rada.gov.ua/laws/show/425-19

6. Rozporyadzhennya Kabinetu Ministriv Ukrayiny`vid 15.11.2017 r. \#909-r «Pro sxvalennya Strategiyi integraciyi vnutrishn`o peremishheny`x osib ta vprovadzhennya dovgostrokovy`x rishen` shhodo vnutrishn`ogo peremishhennya na period do 2020 roku» // Ministerstvo z py`tan` ty`mchasovo okupovany`x tery`torij ta vnutrishn`o peremishheny`x osib Ukrayiny`. / URL: http://mtot.gov.ua/5891-2/

7. Rozporyadzhennya Kabinetu Ministriv Ukrayiny`vid 11.01.2017 r. \#8-r «Pro zatverdzhennya planu zaxodiv, spryamovany`x na realizaciyu deyaky`x zasad derzhavnoyi vnutrishn`oyi polity`ky` shhodo okremy`x rajoniv Donecz koyi ta Lugans 'koyi oblastej, de organy` derzhavnoyi vlady` ty`mchasovo ne zdijsnyuyut`svoyi povnovazhennya» // Oficijny`j veb-portal Verxovnoyi Rady` Ukrayiny`. URL: http://zakon3.rada.gov.ua/laws/show/8-2017-\%D1\%80

8.Zakon Ukrayiny` vid 16.05.2017 r. \#2026-VIII «Pro vnesennya zmin do Zakonu Ukrayiny` «Pro vy`shhu osvitu» shhodo zabezpechennya prava na zdobuttya vy`shhoyi osvity`osib, miscem prozhy`vannya yaky`x ye ty 'mchasovo okupovana tery`toriya Ukrayiny`» // Oficijny`j veb-portal Verxovnoyi Rady` Ukrayiny”.

URL: http://zakon3.rada.gov.ua/laws/show/2026-19

9. Nakaz MON Ukrayiny` \# 50 vid 26.01.2016 "Pro utvorennya Rady` rektoriv vy`shhy`x navchal`ny`x zakladiv, yaki ty`mchasovo peremishheni iz zony` provedennya anty`terory`sty`chnoyi operaciyi" .

URL: http://zakon3.rada.gov.ua/laws/show/2026-19

10. Nakaz MON Ukrayiny` «Pro zatverdzhennya Poryadku pry`jomu dlya zdobuttya vy`shhoyi ta profesijnoyi (profesijno-texnichnoyi) osvity` osib, miscem prozhy`vannya yaky`x ye ty`mchasovo okupovani tery` toriyi u Donecz kij ta Lugans`kij oblastyax». URL: https://zakon2.rada.gov.ua/laws/show/z0907-16

11. https://mon.gov.ua/ua/zhitelyam-donbasu-ta-krimu/studentam/osvitni-centri/osvitni-centri-donbas-ukrayina

12. Xomy`shy`n I. Realizaciya prava na osvitu vnutrishn`o peremishheny`my`osobamy`. URL: http://science.lpnu.ua/sites/default/files/journal-paper/2018/jun/13343/30.pdf

13. Krashhenko Yu., Sorokina G. Umovy`adaptaciyi vnutrishn`operemishheny`x osib do universy`tets 'kogo seredovy`shha zasobamy`students`kogo samovryaduvannya. Vy` toky` pedagogichnoyi majsternosti. 2016. Vy`pusk 17. URL: http://dspace.pnpu.edu.ua/bitstream/123456789/7591/1/Kraschenko.pdf

14. Dub V.G.Adaptaciya studentiv-pereselenciv do vy`shhogo navchal`nogo zakladu URL:https://otherreferats.allbest.ru/sociology/00841607_0.html

15. http://vpl.com.ua/uk/news

\section{Chaltseva O.M. Opportunities and problems of higher education for children from the occupied territories}

In 2014, with the beginning of the Russian aggression, the Ukrainian state was faced with urgent questions regarding the rights of children from the occupied territories. One of these issues was the provision of opportunities to receive higher education for young people who want to study in Ukraine.

In the scientific literature, this problem is not yet sufficiently studied. The analysis of issues related to internally displaced persons was carried out by foreign and domestic scientists through the prism of social, migration, political and legal, psychological aspects.

The article analyzes the legislative opportunities and problems of their implementation, concerning the higher education of children from the occupied territories.

The adopted laws on securing the rights and freedoms of citizens and the legislative regime in the temporarily occupied territory of Ukraine established that citizens of Ukraine who reside in the temporarily occupied territories and persons who were displaced from them have the right to continue their education in another territory of Ukraine at the expense of the state budget.

However, at this point the procedure is not yet established and does not require its own legislative clarification and the destruction of more accurate and sensible mechanisms.

With the help of educational centers "Donbas - Ukraine" and "Crimea - Ukraine", on the basis of the established procedure, children from the territory of the United Forces' operation are able to observe the new directions for obtaining certificates and enrollment in higher educational institutions on the territory of Ukraine.

The main task of educational centers is to provide support and assistance to applicants, who live on the territory of Ukraine, which is not under the control of Ukraine, in obtaining the certificate of complete secondary education and enrollment to Ukrainian universities.

Problems of realization of the right to education include: financial, psychological, social and other problems.

Key words: internally displaced persons, institutions of higher education, higher education, occupied territories, rights of children, adaptation. 